\title{
O nosso querido annus horribilis
}

\author{
RUI PINA COELHO
}

Este será o último número da Sinais de Cena com a Orfeu Negro. O annus horribilis de 2020 veio obrigar a uma redefinição quer do projecto editorial da revista, quer do catálogo da editora. Finda-se aqui uma parceria que possibilitou os primeiros cinco números da segunda série desta revista. São cinco números que correspondem a cerca de 1700 páginas em estudos de teatro e artes performativas publicadas desde 2016, escritas por académicos e artistas portugueses, brasileiros, canadianos, colombianos, espanhóis, franceses, gregos, ingleses, italianos e norte-americanos, dando foco específico a assuntos como «Teatro e Memória», «Genética Teatral», «Teorias da Crítica», «A Prática como Investigação», ou, neste número, «Fernando Pessoa e as Artes Performativas». São cinco números que correspondem também a cerca de sessenta ensaios, trinta críticas a espectáculos, uma dúzia de obras de ou sobre teatro recenseadas; aos portefólios dedicados aos fotógrafos Pedro Soares e José Marques (1924-2012), às companhias Teatro Aberto e malavoadora e ao arquivo do Teatro da Cornucópia, nesta derradeira edição. E também às entrevistas de fundo a Mónica Calle, Jorge Silva Melo, Marlene Monteiro Freitas, Pedro Gil e Luis Miguel Cintra.

No Editorial do primeiro número da segunda série da Sinais de Cena, em 2016, escrevia que nos orgulhávamos «até ao embaraço» do trajecto da revista, de 2004 a 2014, sob a direcção de Maria Helena Serôdio. Cinco anos depois, ainda consigo escrever que me orgulho até ao embaraço do que fomos conseguindo construir com a Orfeu Negro nestes cinco anos.

Mas, apesar do fim desta parceria, a Sinais de Cena, esta prodigiosa invenção de Maria Helena Serôdio e Paulo Eduardo Carvalho, continuará, tentando encontrar o seu espaço e querendo construir um diálogo com os seus leitores que nas suas páginas poderão continuar a procurar $o$ debate, a análise e a avaliação do que no campo do teatro - e de outras artes performativas - se vem praticando nas suas múltiplas vertentes criativas, tanto em Portugal (seu vértice maior de interesse e preocupação), como no resto do mundo. E, do mesmo modo, a Orfeu Negro continuará a ter um dos catálogos em artes performativas mais apetecíveis do país. 
Uma das questões com que sempre nos deparámos ao longo destes anos foi a pertinência e a fluidez do diálogo que conseguíamos estabelecer com o tecido cultural, publicando nós, na primeira série, um número a cada seis meses. A actual periodicidade anual agudiza ainda mais esta dessincronia entre o momento da publicação e o instante presente das práticas cénicas. Mas desta falta de sincronia caminhámos para uma desaceleração. A periodicidade anual desta revista propicia ao leitor um exercício de slow reading. Os muitos ensaios, críticas, recensões, entrevistas e outros textos publicados até agora podem ir sendo degustados ao longo do ano e, em rigor, para lá do quadro temporal a que cada número se reporta. São textos e imagens que transbordam para a feitura da história do teatro e da performance em Portugal, para a crítica das artes performativas, para discussões e leituras em salas de aula e salas de ensaios ou, até, para a construção de espectáculos. Vamos deixando um catálogo de ideias, pensamentos, argumentos, documentos, análises, propostas de leitura e avaliações que podem ir fazendo o seu caminho na articulação com o que se vai pensando sobre a «coisa» teatral e sobre as artes em geral. São páginas pensadas para pessoas curiosas, académicos, artistas, alunos e para todos aqueles que se interessem sobre a matéria teatral ou sobre o mistério da presença humana. Ou seja, dito de outra forma, são páginas pensadas para toda a gente.

No Índice deste número encontramos, como sempre, coisas de hoje e de outrora. Damos eco a fantasmas e medimos a força que as vozes espectrais que assombram o nosso tempo têm ainda naquilo que fazemos e vemos, nos palcos e na vida. O teatro de Fernando Pessoa e o curioso diálogo trans-histórico que este estabelece com a dramaturgia contemporânea; uma viagem pelo Arquivo do Teatro da Cornucópia, legado à Biblioteca da Faculdade de Letras da Universidade de Lisboa; e a voz tonitruante e humana de Luis Miguel Cintra surgem aqui para dialogar com os desafios que as artes performativas vão enfrentando hoje. Num ano tão - como dizer? - atípico como o de 2020, ficam aqui também relatos de experiências de espectadores que viram espectáculos ao vivo e em linha, oferecendo as reflexões possíveis, provisórias e transientes, sobre as novas provas que os formatos «pandémicos» vieram provocar. Por último, as recensões a obras de e sobre teatro que aqui publicamos permitem que muitos desses livros se destapem e voltem a conversar com os leitores.
Tudo isto, já se percebe, são gestos pequeninos, delicados, invisíveis. São pequenas formas de irmos exercitando o músculo da participação crítica no mundo e de irmos resistindo ao confinamento da esfera pública. São gestos, já se percebe, de impenitentes resistentes, ávidos de conversar com o mundo. São gestos, já se percebe, de amor. 